\title{
Quantitative environmental impact assessment of the Open cast mining in Sonbhadra district, Uttar Pradesh, India
}

\author{
Ajai M ishra* and Vinay K umar Pandey ${ }^{1}$ \\ Department of Geology, University of Lucknow, Lucknow-226007 (U.P.), INDIA \\ ${ }^{1}$ GIPL, Energy Division, $5^{\text {th }}$ floor, Orbit Plaza, New Prabhadevi road, Prabhadevi, Mumbai (Maharastra), INDIA \\ *Corresponding author. E-mail: ajaimishra2007@yahoo.co.in
}

Received:J une 23, 2013; Revised received:August 14, 2013; Accepted:August 22, 2013

\begin{abstract}
The district Sonbhadra, previously a part of Mirzapur district in Uttar Pradesh, India, was created as a separate district in 1991.Geologically the area consists of Vindhyan supergroup, Mahakoshal group and Dudhi granitoid complex.The district Sonbhadra has rich mineral resources and their potential. The area is known for production of cement grade Limestone and Dolomite; the other minerals are Clay, Calcite, Silimanite and base metals for more than last three decades. These mining areas show impacts on the environmental status of the district. In the present study, the different mining and environmental parameters have been considered for analysing the environmental impact assessment (EIA). A matrix method has been used to delineate the quantitative EIA in the area. Finally, the resulted assessment impact value index (-2861.76), shows significant impact on environment such as degradation of forest land, air contamination due to mining dust, water quality and related health aspect of the area. Thus, major environmental control measures should be taken for sustainable development of the study area such as improvement of mining equipments, proper dumping of the mining waste and large scale plantation.
\end{abstract}

Keywords: Environmental impact assessment, Environmental parameters, Matrix method, Parameter importance value

\section{INTRODUCTION}

The district of Sonbhadra lies in the south-eastern part of the state of Uttar Pradesh; bounded by the Latitude23051' 54" N - 24046' 18" N, Longitude- 82 $40^{\circ}$ ' 24" E $83^{\circ} 33^{\prime} 15$ " E. It is covered in the Survey of India topographical sheet no $63 \mathrm{P}, \mathrm{L}$ and $64 \mathrm{I}$ and $\mathrm{M}$, on a scale of 1:2,50,000. It is bounded by Mirzapur and Chandauli in the north, Jharkhand in the east, State of Madhya Pradesh in the west and Chhattisgarh in the south (Fig. 1).

The district Sonbhadra occupies a geographical area of $6788 \mathrm{Sq} \mathrm{km}$. In the year 2011, It has a population of 18,62,612 of which male and female were 9,73,480 and 8,89,132 respectively. Average literacy rate in 2011 is 66.18 (male 77.19 and female 54.11) with compare to 49.22 (male 62.95 and female 32.70) in year 2001. There was a change of $27.27 \%$ in the population compared to the population as per 2001. In the previous census of India 2001, Sonbhadra district recorded an increase of $36.28 \%$ to its population compared to 1991 . The population density is 274 in 2011 as compared to 215 of 2001 and 158 per square $\mathrm{km}$ in 1996. The district was previously a part of Mirzapur district. It was created as a separate district in 1991 (DES, 2011).

\section{GEOLOGY AND GEOMORPHOLOGY}

The area is mainly drained by the river Son, Rihand, Kanhar, Karamnasha, Gaghar, Belan and their tributaries. ISSN : 0974-9411 (Print), 2231-5209 (Online) All Rights Reserved ๑ App
The river Son enters the area at Kalighat and after flowing for a distance of nearly $60 \mathrm{~km}$ due east, leaves the area about $15 \mathrm{~km}$ north-east of the Kon area and enters the state of Bihar. In the area the river Son forms a deep cut valley about $12-15 \mathrm{~km}$ wide. The important north bank tributary of Son river is Ghaghar and South bank tributary is Kanhar river. (Fig. 2)

Topographically, the area is divided into three units viz. (i) Table 1 and stretching from summits of Vindhyan scarp to the Kaimur range (ii) Valley of Son river (iii) Hills, valleys and jungle clod ravines. The tableland forms a part of the Kaimur plateau with minor undulations and a sharp line towards south which separates it from the valley of Son river. The height of the plateau ranges from approximate 250-400 m above mean sea level. The valley of Son river lies south of the table land whose elevation ranges from $150-200 \mathrm{~m}$. The area south of Son valley is marked by hills, valley and forests with an elevation ranging from 200-400 m(Shukla, 1991).

Geologically, Sonbhadra district consists of Dudhi granitoid complex, Mahakoshal group, Vindhyan supergroup and the recent alluvium occur in narrow strip along Son river and other stream courses. Only the Semri and Kaimur groups are present in the Sonbhadra district consisting of limestone and sandstone. The rock of the Semri group consists of basal conglomerates and 


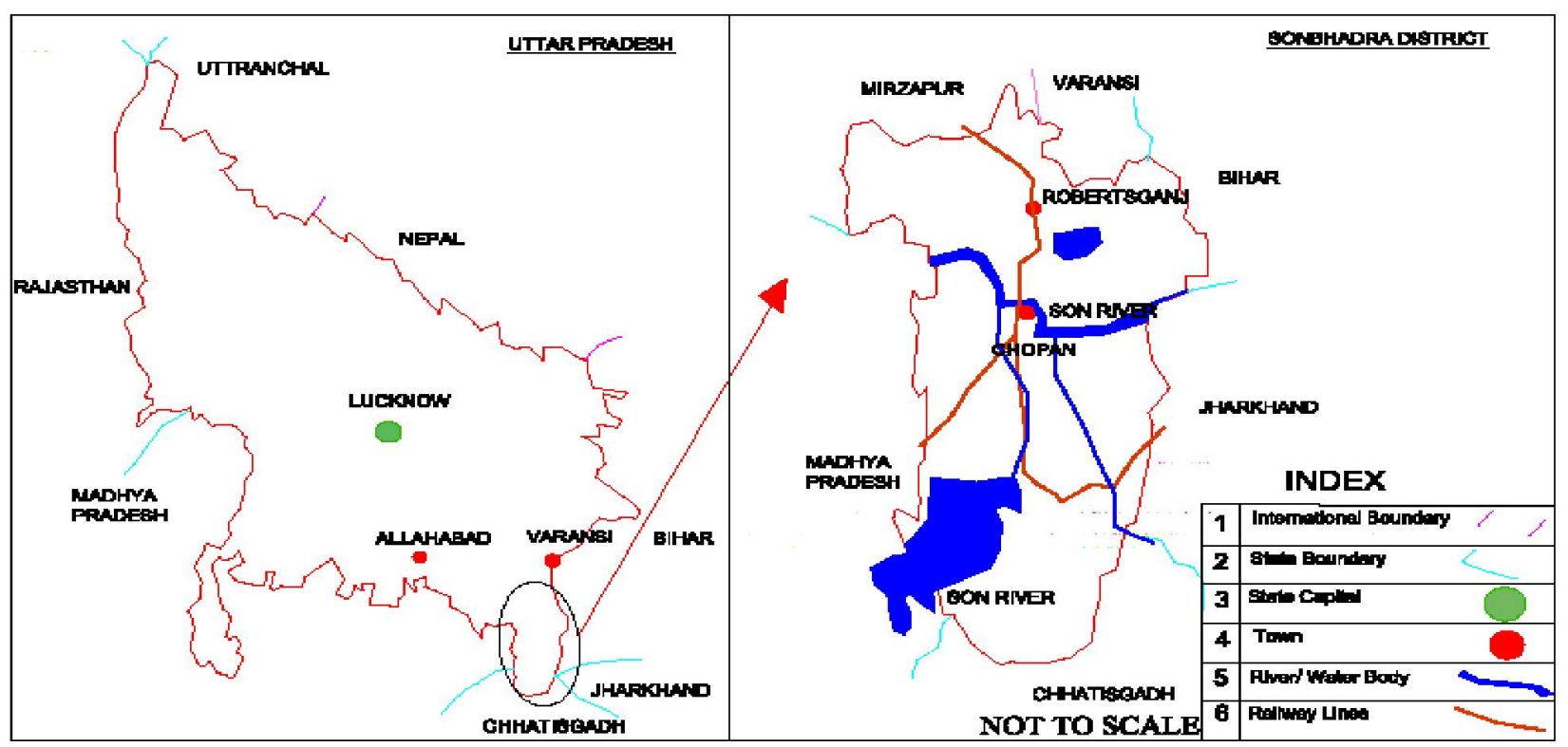

Fig. 1. Location map of Sonbhadra district

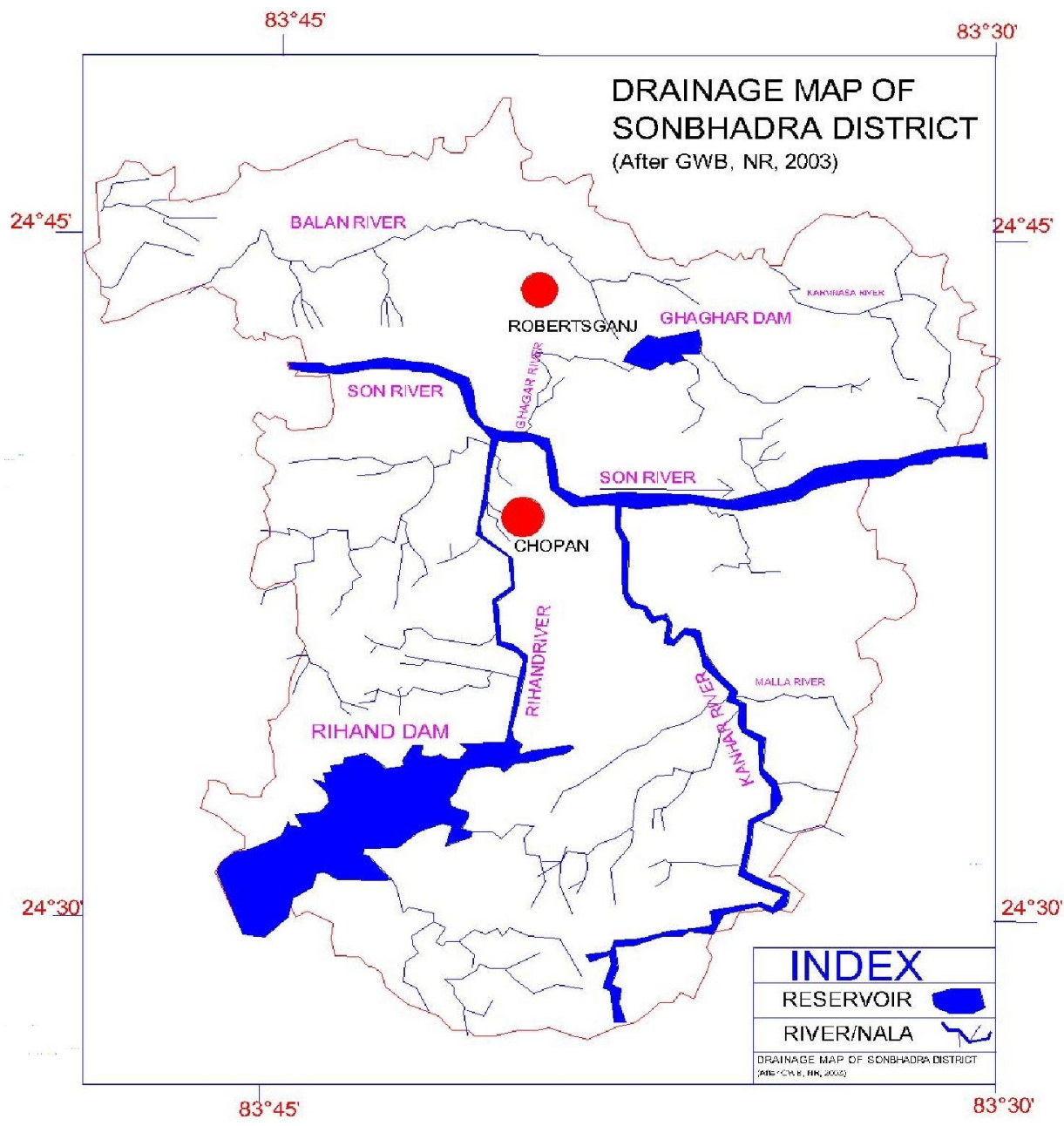

Fig. 2. Drainage map of Sonbhadra district

Limestone, lying unconformable on the schist, phyllites of the Mahakoshal group and on the granites of Dudhi granitoid complex (Srivastava et. al., 2000) (Fig. 3).

The climate of the area differs from other districts of the state. The coldest month is January with a mean monthly temperature of $9.2^{\circ} \mathrm{C}$ and hottest month is May with mean temperature reaches up to $41^{\circ} \mathrm{C}$. The climate of the district is sub-humid. Most of the rainfall occurs during 


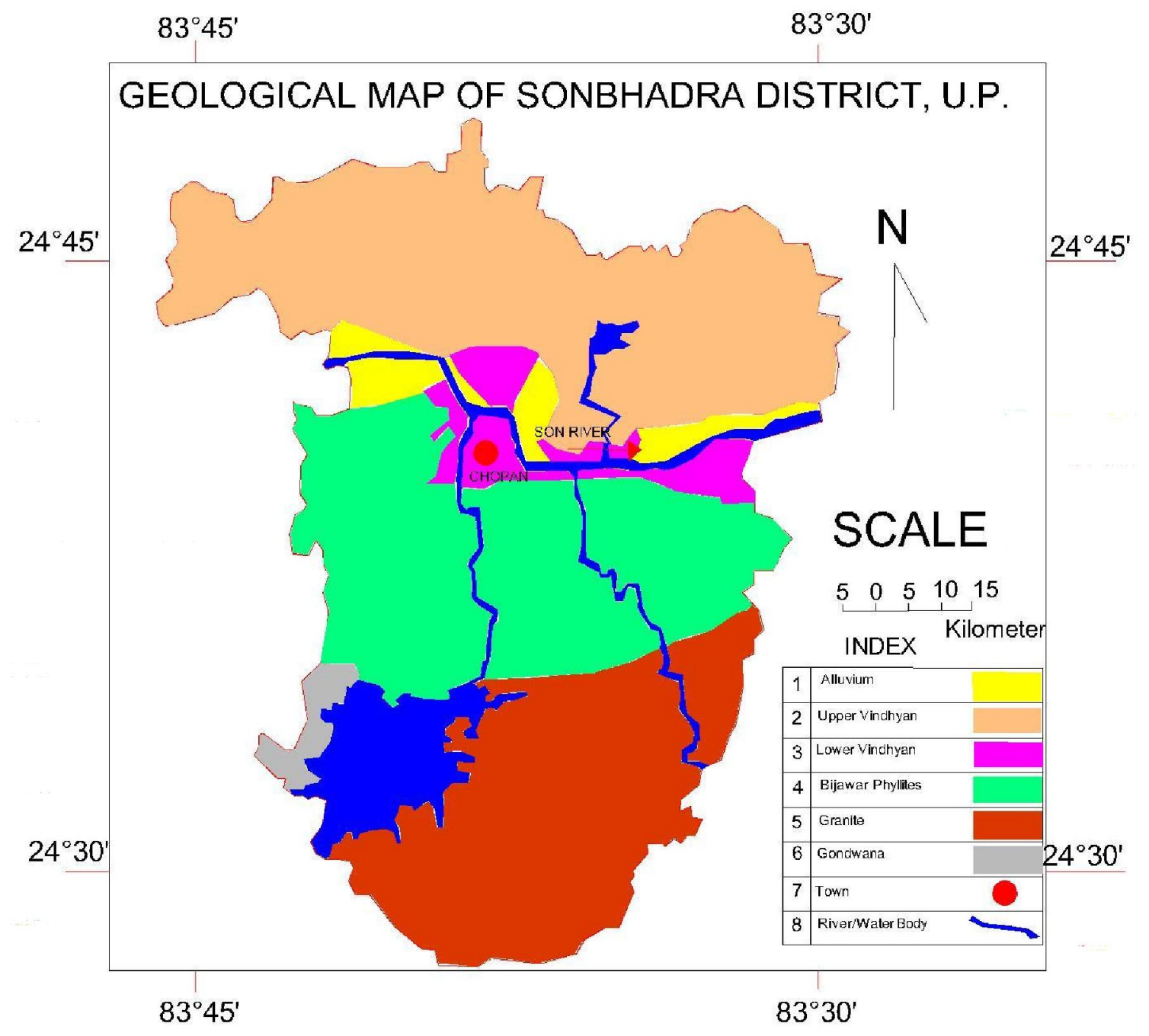

Fig. 3. Geological map of Sonbhadra district.

monsoon season between June to September every year, average rainfall of the district being $1065 \mathrm{~mm}$.

\section{MINERAL RESOURCES IN SONBHADRA DISTRICT}

Sonbhadra district has rich mineral resources. Government organisations as well as private lease holders are doing mining in these areas. The ongoing mineral investigation programmes in Sonbhadra district by Directorate General of Geology and Mines, Uttar Pradesh (DGM, 2006) are given below:

1. China clay in Naudiha-Ramgarh - advanced stage

2. Sillimanite in Chhipiya area - advanced stage

3. Cement grade limestone in Ghaghar - advanced stage

4. Placer gold in Hardi-Bagisoti - preliminary stage.

5. Base metals in Deva-Injani - preliminary stage.

\section{METHODOLOGY}

Environmental impact assessment (EIA) is the documentation of an environmental analysis which includes identification, interpretation, prediction and mitigation of impact caused by a proposed action or project (Chaudhari, 1992).

Opencast mining is the main method of mining in the area. It can have significant impact on the environmental status of the district (Fig 4). EIA is a process, used to identify the environmental, social and economic impact of area prior to decision making. It is a decision making tool, which guides the decision makers to taking appropriate decisions for appropriate area (Guidance Manual for Mining of Mineral, MoEF, Govt of India, 2010). The quantitative analysis process involves the major elements of identification, measurement, interpretation and communication of impacts. However, the measurement techniques vary, interpretations vary from impacts which are adverse to those which are beneficial, and decision makers are faced with balancing of these projects pros and cons to reach an 'equitable' or 'promising' decisions. So, a number of methods have been developed which are based upon the way impacts are identified (EIA, 1970; Singh, 1980).

In the present study, we have carried out quantitative analysis of EIA of the open cast mining using the matrix method. 


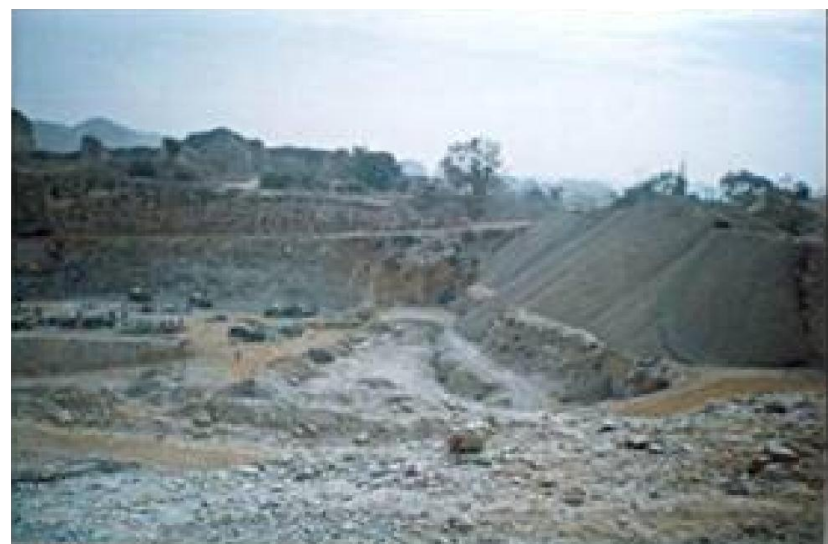

1. Mining at Billi area.

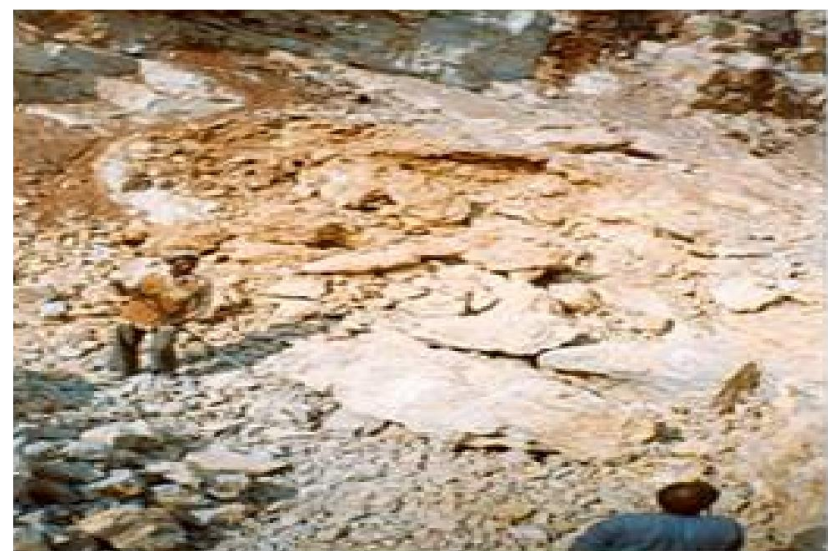

3. M anual mining, near $D$ ala area.

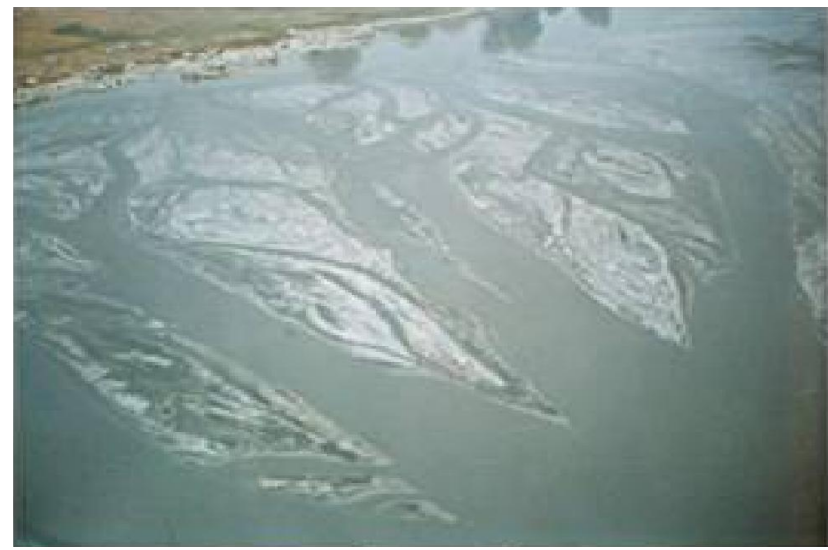

5. Dust in Rihand river at Obra

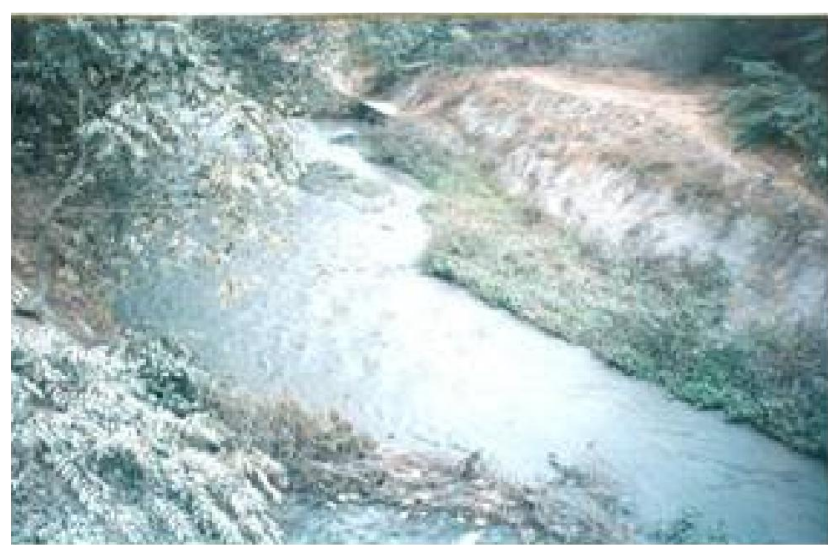

7. Vegetation covered by dust near mining area.

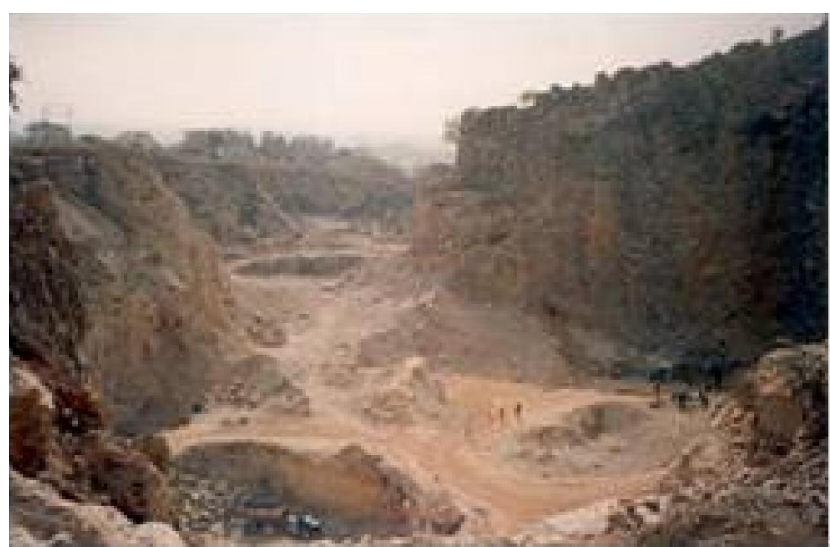

2. Bench mining at $\mathrm{D}$ ala area.

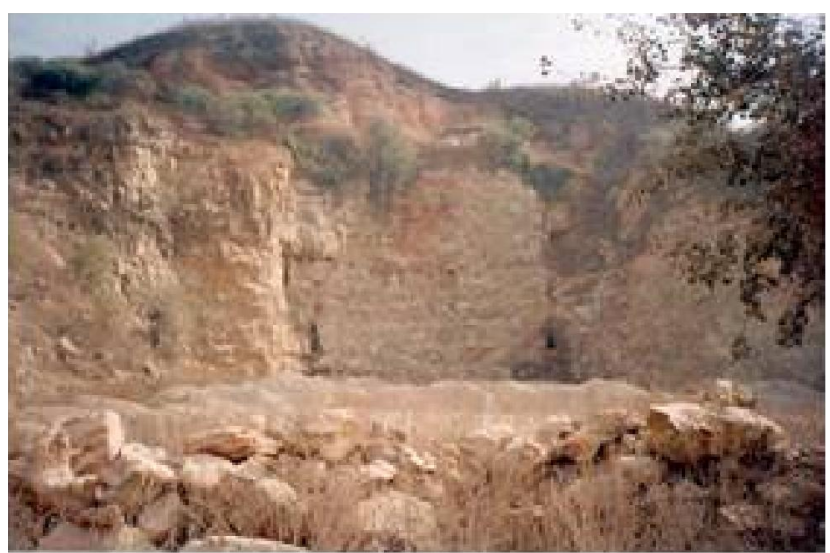

4. Unscientific mining at $D$ ala area

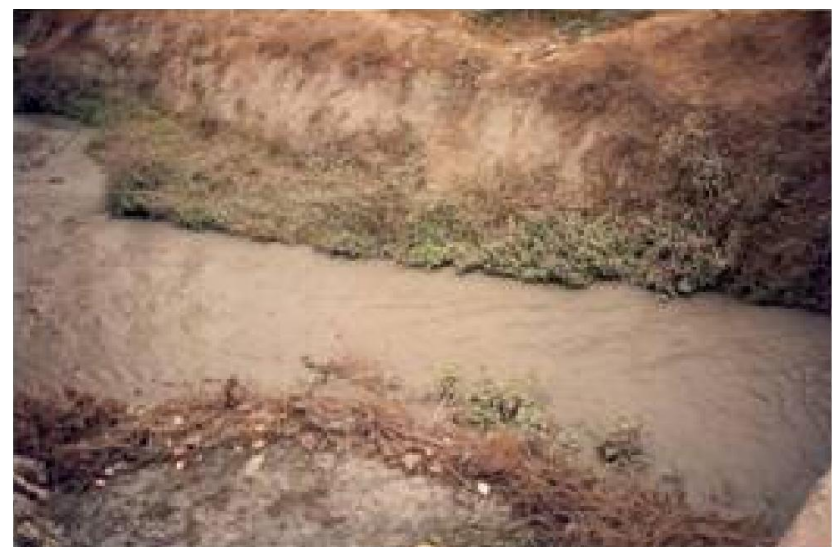

6. Water pollution by mining dust, $\mathrm{Obra}$

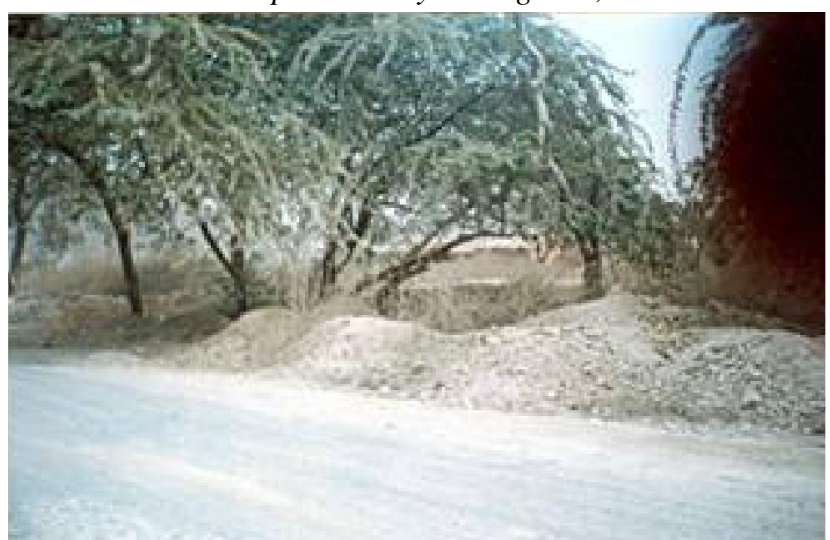

8. Vegetation covered by dust 


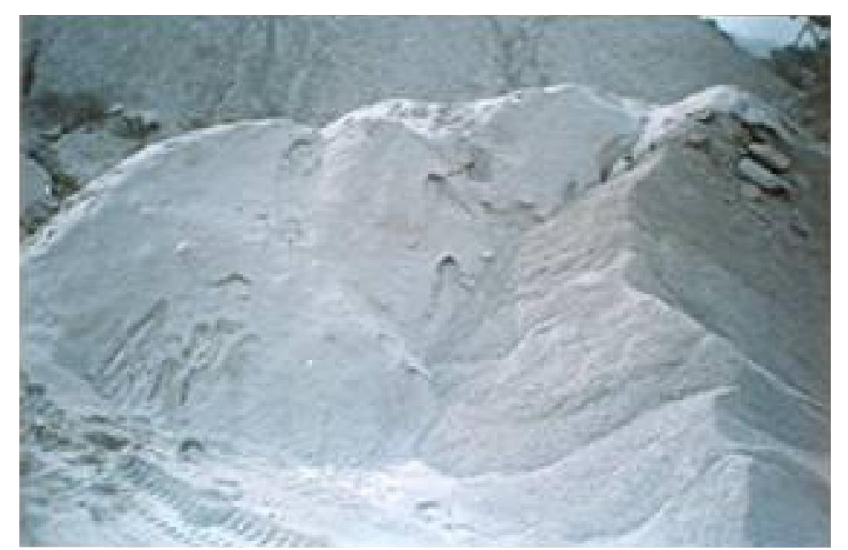

9. Dust at rock Cursing, Near Shobha Industries, Chopan

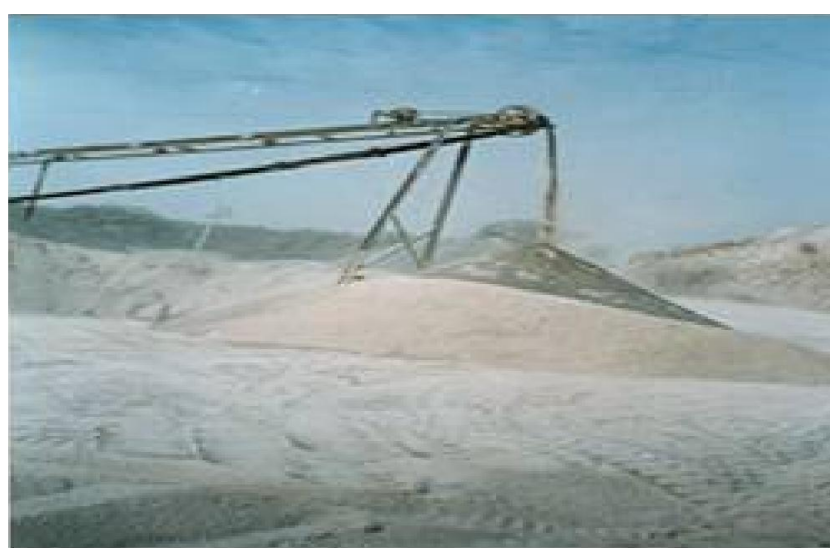

10. Dust at rock C ursing, Near Shobha Industries, Chopan

Fig. 4. Field photographs showing Environmental impact due to mining.

Table 1. Minerals present in Sonbhadra district (Source: DGM, 2006).

\begin{tabular}{|c|c|c|c|c|c|}
\hline S. No. & M ineral & Locality & $\begin{array}{c}\text { Reserves } \\
\text { (In lakh tonnes } \\
\text { as on M arch } \\
\text { 31, 2006) }\end{array}$ & $\begin{array}{l}\text { A pprox. } \\
\text { A mount } \\
\text { (In crore } \\
\text { rupees) }\end{array}$ & Uses \\
\hline 1 & China clay & $\begin{array}{l}\text { Naudiha, Ramgarh, } \\
\text { Garda }\end{array}$ & 165.0 & 6505.00 & $\begin{array}{c}\text { Ceramics, refractory } \\
\text { industry }\end{array}$ \\
\hline 2 & Coal & $\begin{array}{l}\text { Kakri, Bina, } \\
\text { Dhughichua, } \\
\text { Kharia }\end{array}$ & 7220.00 & 65702.00 & $\begin{array}{l}\text { Thermal power, } \\
\text { Cement, Ceramics } \\
\text { industries etc. }\end{array}$ \\
\hline 3 & Dolomite & Bari & 200.00 & 340.00 & Iron \& steel Industry \\
\hline 4 & Limestone & $\begin{array}{l}\text { Bhalua, Kajrahat, } \\
\text { Billi, Ghurma }\end{array}$ & 4000.00 & 6840.00 & $\begin{array}{c}\text { Cement \& steel } \\
\text { Industry }\end{array}$ \\
\hline 5 & Silimanite & Chhipiya & 32.00 & 1659.200 & Refractory industry \\
\hline
\end{tabular}

M atrix method: The 'Matrix method' incorporates in case of open cast mining in Sonbhadra district, Uttar Pradesh. For a semi-quantitative assessment of environmental impact, the matrix which incorporates the same cause and effect relationship between a list of project activities and affected environmental attributes has been used in mining areas. The Matrix method was initially developed by Leopold (1971). His method consists of a matrix which is primarily a check list designed to show possible interactions between development activities and a set of environmental characteristics. One hundred different types of impacts and eighty eight environmental characteristics were identified in the system giving a total of 8800 possible interactions. In practical, it can be reduced to similar number of related items.

Lohani and Thanh (1980), has evolved a simple formula based on the principal to assist in the identification of major activities and impact areas requiring greater attention. In this method relative weight is assigned to the development activity. The total value of activity (vertical sum) is given as n

Pi $\Sigma=1$ (Iii Mii)

$\mathrm{i}=1$

and the total value of all the interactions is given as: $\mathrm{n}$

$\Sigma=$ Pi (Iii) (Mii)

$\mathrm{i}=1$

where, Mii and Iii are the magnitude and importance of the interaction between $\mathrm{i}^{\text {th }}$ activity and $\mathrm{I}^{\text {th }}$ impact \& Pi as the relative weight of the $i^{\text {th }}$ activity.

The 'Matrix method' basically incorporates a list of project activities or actions with a check list of environmental conditions or characteristics that might be affected. Combining these lists as horizontal and vertical axes for a matrix allows the identification of cause-effect relationships between specific activities and impacts. The entries in the cell of the matrix can be either qualitative estimates or quantitative estimates of these cause-effect relationships. The latter are in many cases combined into a weighted scheme leading to a total 'impact score' (Chaudhari, 1992).

CMPDI (Central Mining Planning and Design Institute, 
Table 2. Impact values were assigned as per scheme.

\begin{tabular}{cll}
\hline $\begin{array}{c}\text { Impact } \\
\text { value }\end{array}$ & Impact nature & Remarks \\
\hline 0 & No impact & \\
0.5 & Slight impact & \\
1 & Appreciable impact & $\begin{array}{l}\text { +sign denotes } \\
\text { beneficial impact } \\
\end{array}$ \\
2 & Significant impact & $\begin{array}{l}\text {-sign denotes } \\
\text { adverse impact }\end{array}$ \\
3 & Major impact & (For Table no 3) \\
4 & High impact & \\
5 & Severe / Permanent & \\
& impact & \\
\hline
\end{tabular}

1986) (A Subsidiary of Coal India Limited, Govt of India) has developed a similar environmental impact matrix in which environmental attributes have been located in rows and activities having impact on attributes are placed in columns. Positive and negative signs are assigned to the impact value to show beneficial or adverse effects. Each attribute has also been assigned a value depending on its relative weightage for protection/improvement of environment and is placed as the first column. Row-wise and column-wise score was obtained as in the Lohani and Thanh methods (1980). Taking into consideration the degree of stress that these activities are likely to impose cumulatively, each Impact area has been ranked on a scale of 1 to 6 to arrive at the Parameter importance

Table 3. Importance value of Environmental parameters-Sonbhadra

\begin{tabular}{|c|c|c|c|c|c|c|c|c|c|c|}
\hline \multirow[t]{2}{*}{ S.No. } & \multirow{2}{*}{$\begin{array}{l}\text { Envir onmental } \\
\text { par ameter s }\end{array}$} & \multicolumn{6}{|c|}{ Ranking } & \multirow[t]{2}{*}{ Total } & \multirow[t]{2}{*}{ W eight-age } & \multirow{2}{*}{$\begin{array}{l}\text { Parameter } \\
\text { impor tance } \\
\text { value (PIV) }\end{array}$} \\
\hline & & 1 & 2 & 3 & 4 & 5 & 6 & & & \\
\hline 1 & $\begin{array}{l}\text { Land use \& soil } \\
\text { characteristics }\end{array}$ & & & & & & $*$ & 6 & $6 / 58$ & 103.45 \\
\hline 2 & $\begin{array}{l}\text { Surface water } \\
\text { resources }\end{array}$ & & & & $*$ & & & 4 & $4 / 58$ & 68.96 \\
\hline 4 & $\begin{array}{l}\text { Ground water } \\
\text { resources }\end{array}$ & & & & & $*$ & & 5 & $5 / 58$ & 86.21 \\
\hline 5 & Air quality & & & & $*$ & & & 4 & $4 / 58$ & 68.96 \\
\hline 6 & Noise & & & & $*$ & & & 4 & $4 / 58$ & 68.96 \\
\hline 7 & Ground vibration & & $*$ & & & & & 2 & $2 / 58$ & 34.48 \\
\hline 8 & Flora & & & $*$ & & & & 3 & $3 / 58$ & 51.72 \\
\hline 9 & Fauna & & & $*$ & & & & 3 & $3 / 58$ & 51.72 \\
\hline 10 & Socio economics & & & & & & $*$ & 6 & $6 / 58$ & 103.45 \\
\hline 11 & Civic amenities & & & & $*$ & & & 4 & $4 / 58$ & 68.96 \\
\hline 12 & Health and safety & & & $*$ & & & & 4 & $4 / 58$ & 68.96 \\
\hline 13 & Aesthe tics & & & $*$ & & & & 3 & $3 / 58$ & 51.72 \\
\hline 14 & $\begin{array}{l}\text { Human settlements and } \\
\text { historic buildings }\end{array}$ & & & & & & $*$ & 6 & $6 / 58$ & 103.45 \\
\hline
\end{tabular}

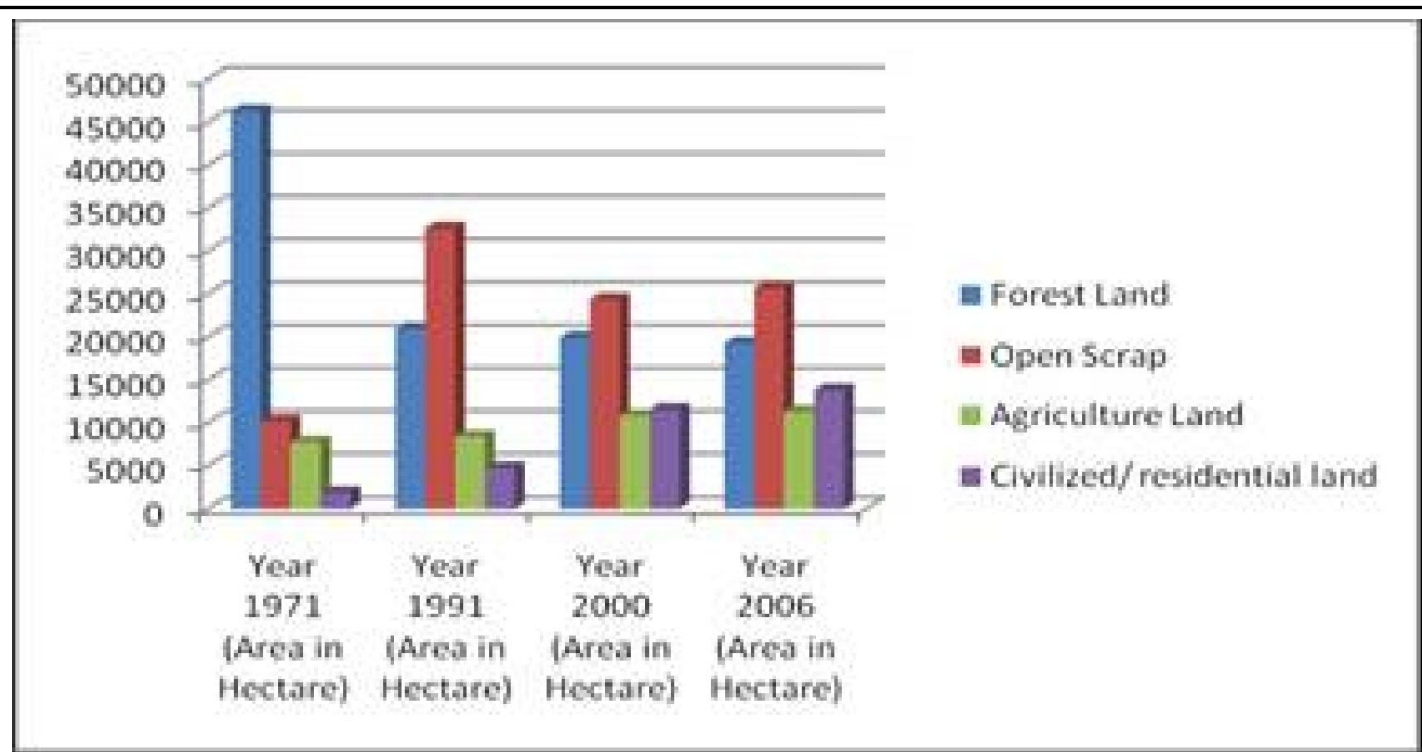

Fig. 5. Comparative bar-chart of Land use pattern year 1971, 1991, 2000 and 2006. 
Table 4. Environmental impact matrix without protective measures.

\begin{tabular}{|c|c|c|c|c|c|c|c|c|c|}
\hline \multirow[t]{2}{*}{$\mathrm{PIV}$} & \multirow[t]{2}{*}{ Environmental parameters } & & \multicolumn{6}{|c|}{ Mining activities } & \multirow[t]{2}{*}{$\begin{array}{l}\text { Total impact } \\
\text { score }\end{array}$} \\
\hline & & $\begin{array}{l}\text { O } \\
. \underline{\Sigma} \\
\qquad \\
\Sigma\end{array}$ & 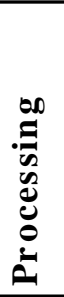 & 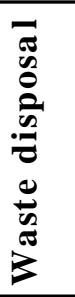 & 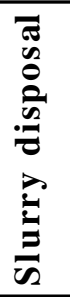 & 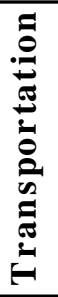 & 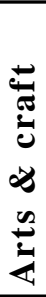 & 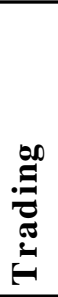 & \\
\hline 103.45 & Land use and soil & -5 & -3 & -4 & -3 & 1 & & 3 & -1137.95 \\
\hline 68.96 & Surface water resources & -2 & -2 & -2 & -2 & & & & -551.68 \\
\hline 68.96 & Ground water resources & -2 & -2 & -2 & -2 & & & & -551.68 \\
\hline 86.21 & Water quality & -3 & -2 & -3 & -4 & & & & -1034.52 \\
\hline 68.96 & Air quality & -3 & -3 & -3 & -3 & -2 & & -1 & -1034.40 \\
\hline 68.96 & Noise & -4 & -4 & -3 & -3 & -4 & & -2 & -1379.20 \\
\hline 34.48 & Ground vibration & -3 & -3 & & & & & & -206.88 \\
\hline 51.72 & Flora & -2 & -1 & -1 & 3 & 3 & 1 & -1 & 103.44 \\
\hline 51.72 & Fauna & -2 & -2 & 2 & 2 & 3 & & 3 & 310.32 \\
\hline 103.45 & Socio economics & 4 & 4 & 2 & 2 & 4 & 3 & 3 & 2275.90 \\
\hline 68.96 & Civic amenities & & & -1 & -1 & -1 & 2 & 2 & 68.96 \\
\hline 68.96 & Health and safety & -4 & -1 & -2 & -2 & 2 & & 2 & -344.80 \\
\hline 51.72 & Aesthetics & -3 & -2 & -3 & -1 & -2 & 5 & & -310.32 \\
\hline 103.45 & $\begin{array}{l}\text { Human Settlements and } \\
\text { historic buildings }\end{array}$ & -2 & 1 & 2 & 2 & 2 & 2 & 2 & 931.05 \\
\hline
\end{tabular}

value (PIV).

The impact values were assigned as per scheme shown in Table 2.

Impact value of each parameter was multiplied by the weightage values allotted to the corresponding parameter. This gave final score in terms of environmental impact units. Summing up the final score gave EIA of the entire project / mining area.

\section{RESULTS AND DISCUSSION}

Mining activities have been continuously going on from the last three decades and there are many mineral based industries also running in the area. Previously the following authors Jain, Urban, and Stacey, 1971, Down and Jonson, 1977, Chaudhari, 1992, CEAA, 1999, Mahatha and Dutta 2003; Datta et al., 2004; have been described the EIA parameters of the present area, only qualitatively. Few remedial and precautionary measures have been suggested such as to formulate by-law and their strict compliance by centralised government body, protection of natural ecosystem by proper implementation of muck disposal, good machineries, plantation along mines etc (Sinha, 1982-83). In the present study this quantative matrix method used first time for the calculation of the EIA in Sonbhadra district. The mining activities which have impacts on various environmental parameters in study area are enumerated below:-

On the basis of project activities done during open cast mining the changes in landuse from year 1971 to year 2006 are recorded such as forest land decreases rapidly and become nearly half, open scrap land get 2.5 times higher, agriculture land become 1.5 times higher and residential land become 7.5 times higher with compare to year 1971 (Fig. 5). We have given the ranking for different project activities in environmental impact matrix (Pandey, 2012).

M ethod for calculating PIV: Refer Table 4, For each environmental parameters as Land use and Soil characteristics; considered the Ranking on the subjective judgment of study area 6 . Same process for Surface water resource takes ranking 4 and so on. Finally find the total of all the given ranking $\Sigma$. Each ranking is divided by Ó and multiplied by 1000 , result is PIV.

Ranking of Land use and Soil characteristics $=6$, AND Ó $=58$

$\mathrm{PIV}=6 / 58=0.103445 \times 1000=103.45$

This score has been evaluated against an assessment value index scale, which is given below:

The present study was focussed on EIA by Matrix method and the impact score we have obtained for the study area is (-2861.76). This score has been shown as per assessment value index scale table; it has led to a 
significant impact on environment.

\section{Conclusion}

It can be undoubtedly said that environmental consciousness arising out of mining and associated impacts is achievable through joints efforts of agencies doing research and development and monitoring work on various parameters. Mining and related activities have major beneficial impacts on socioeconomics of the entire region. Mining has appreciable adverse impact on human settlements in the study area and slight beneficial impact on provision of civic amenities in the area. Amalgamation of small lease holds and mining on co-operative basis needs to be explored in consultation with mine owners, government representatives and environmentalists for sustainable development of the mining area. In addition to remedial measures, vegetation screens all around mining belt, stabilization of overburden dumps, and realignment of railway lines are suggested for environmental management of the area. People should have a moral responsibility of conserving their environment.

\section{REFERENCES}

CEAA (1999). Canadian Environmental Assessment Agency. Cumulative effects assessment practitioners guide. Hull, Quebec. Catalogue no En106-44/1999E.

Chaudhari, A. B. (1992). Mine, Environment and Management, an Indian Scenario. Ashish Publishing House, New Delhi, 158-188.

CMPDI (1986). Environmental Impact Assessment of Mining. Central Mining Planning and Design Institute, India.

DES (2011). Statistical Diary, District. Sonbhadra, Uttar Pradesh. D epartment of E conomics and Statistics, U .P India. DGM (2006). Sonbhadra Mineral Resources, Directorate
General of Geology and Mines, Lucknow, U. P. India.

Down, G. and Jonson (1977). Environmental Impact of Mining. Applied Science Publication Ltd, London.

EIA (2010). Environmental Impact Assessment-Guidance manual of mining of minerals, Ministry of Environment and Forest, Government of India.

Jain, R. K., Urban, L. V. and Stacey, G S. (1971). Environmental Impact Analysis- A New Dimension in Decision Making. Publisher Van N ostr and Reinhold Company, New York.

Leopold, L. B., Clarke, F. E., Hanshaw, B. B., and Balsley, J. R. (1971). A procedure for evaluting environmental impact. U.S. Geological Survey Circe, 645. Washington

Lohani, B.N. and Thanh, N.C. (1980). Impact of Rural Development and their assessment in Southeastern Asia. Environmental Conservation, 7(3): 213-216.

Mahatha, S. and Dutta, P. (2003). Incorporating cumulative impact concerns into EIAs. Mining Environmental M anagement, 11(2): 16-21.

Pandey, V.K. (2012). Geoenvironmental impact analysis of open cast mining in Sonbhadra district, U.P., India. Ph.D. Thesis. Geology Department, Lucknow University, Lucknow, U.P., India.

Sinha, A. K. (1982-83). Environmental studies of the developing mineral based industrial belt in Chopan-Robertsganj area, Mirzapur district, U.P., India. Geological Survey of India, Lucknow, India.

Singh, K.N. (1980). Quantitative analysis of landforms and settlements distribution in southern uplands of eastern U.P. (India). Vimal Prakashan.

Shukla, Sanjay (1991). Geomorphological study of eastern part of Son valley, Sonbhadra Distt, U. P. with special reference to landuse. J ournal of Indian N ational G eographers, India. $6: 97-102$.

Srivastava A. K., Shukla, Sanjay and Kumar, Hemant (2000). Baghisoti pluton: A peraluminous granitoid in the parsoi formation, Mahakoshal group, Sonbhadra Distt., Uttar Pradesh, India. Geoscience J ournal, 11(2): 147-160. 